\title{
Efficiency Play, Games, Competitions, Production - How to Analyze the Configurations of Sport? ${ }^{1}$
}
Authors' contribution:
A) conception and design of the study
B) acquisition of data
C) analysis and interpretation of data
D) manuscript preparation
E) obtaining funding

\author{
Henning Eichberg \\ University of Southern Denmark, Denmark
}

\section{KEYWORDS}

\begin{abstract}
The comparative, differential phenomenology of play and games has a critical political point. A mainstream discourse identifies - more or less - sport with play and game and describes sport as just a modernized extension of play or as a universal phenomenon that has existed since the Stone Age or the ancient Greek Olympics. This may be problematical, as there was no sport before industrial modernity. Before 1800 , people were involved in a richness of play and games, competitions, festivities, and dances, which to large extent have disappeared or were marginalized, suppressed, and replaced by sport. The established rhetoric of "ancient Greek sport", "medieval tournament sport", etc., can be questioned.

Configurational analysis as a procedure of differential phenomenology can help in analyzing sport as a specific modern game which produces objectified results through bodily movement. This analysis casts light not only on the phenomenon of sport itself, but also on the methodological and epistemological challenge of studying play, movement, and body culture.

configurational analysis, differential phenomenology, historical relativity, basis and superstructure, modernity, riding, space, time, energy
\end{abstract}

Sport idealism, which is dominating large parts of sport research, assumes that sport is a universal phenomenon under the heading of play and game. In a logical and progressive way, as one says, sport continues and extends the old popular games. One speaks about the Olympic "Games", and by this use of language, one places Olympic and competitive sport on one line with children's play and with traditional folk games like the Scottish Highland Games. In this imagination, sport is a natural continuation of traditional play, or even a reawakening of ancient games, in modern form.

In contrast to this idyllic picture of tradition and progression, the critical research since Norbert Elias has revealed and documented the historical and cultural relativity of sport. Sport is a particular Western and modern phenomenon. Throughout history, movement culture has changed patterns again and again, and sport is a specific innovation from industrial culture based on the principle of achievement and rationality directed

\footnotetext{
${ }^{1}$ A previous version of this article was published in Danish in: P. Mindegaard, S. Andkjær, \& A. M. Svendsen (2014) (eds.). Bevægelser og kropskulturelle mønstre. Konfigurationsanalysen i teori og praksis /Movements and body cultural patterns. Configurational analysis in theory and practice/ (pp. 133-146). Odense: Syddansk Universitetsforlag.
} 
towards the measurement of results. Here, we will outline this critical discovery and show the methodological challenge that it implies for an analysis of play that avoids the idealistic constructions of continuity and "ancient roots".

\section{From courtly riding to horse races with a stopwatch}

Riding as play, game, and exercise can be taken as the initial case (Eichberg, 1978, pp. 31-45). During the Middle Ages, knights held tournaments with heavy weapons. Their tournaments were sometimes imitated or conducted in a carnival-like and burlesque way parodied by farmers and townspeople.

During the sixteenth and seventeenth centuries, however, the patterns changed towards the so-called horse ballets and carousels in courtly society. Here, equestrians followed certain geometrical figures. In connection with this, between Federigo Grisone in 1552 and Antoine de Pluvinel in 1623/25, the upper classes developed classical figure riding. The movement was derived from the regulated positur of equestrians and horses. Basic geometrical figures - circles, straight lines, diagonals, voltes, and serpentine lines - determined the choreography of the horse and rider right up to the artificial turning of the pirouette. Moving the horse "above the earth" made up the "High School" of riding art, with its artificial figures, such as levades, courbettes, mazair, croupades, ballotades, caprioles, and falcades. Accompanied by music and sometimes set in theater-like narratives, riding became a geometrical "gesamtkunstwerk".

The geometrical patterns of riding corresponded to changes that occurred in other aristocratic exercises at the same time. Courtly dance developed the minuet on geometrical choreographies. Vaulting formalized jumping on a wooden horse in highly elaborated forms, and fencing regulated steps and epee through geometrical patterns. The common denominator of these exercises was a sort of social geometry.

The other social classes were excluded from this social geometrical pattern of the nobility, with the exception of some exercises at universities and military exercises. Social geometry was connected with social exclusion according to the new hierarchies of social classes, which formed the basis for the new state of Absolutism.

In order to characterize the absolutist society of the seventeenth and eighteenth centuries as a whole, this process has been termed "social discipline", Sozialdisziplinierung (Oestreich, 1969). This description fits quite well; however, the process went much broader and deeper than the socio-political scale, and deeper than the state of Early Modernity. This is what play and dance show. Furthermore, patterns of social geometry appeared in the field of military technology - through fortification, systematic attack, and battle formation as well as in architecture through the planning of the ideal city (Eichberg, 1989). Foucault (1966) has shown how during the "classical age" of the seventeenth and eighteenth centuries, the tableau as a quasi-geometrical

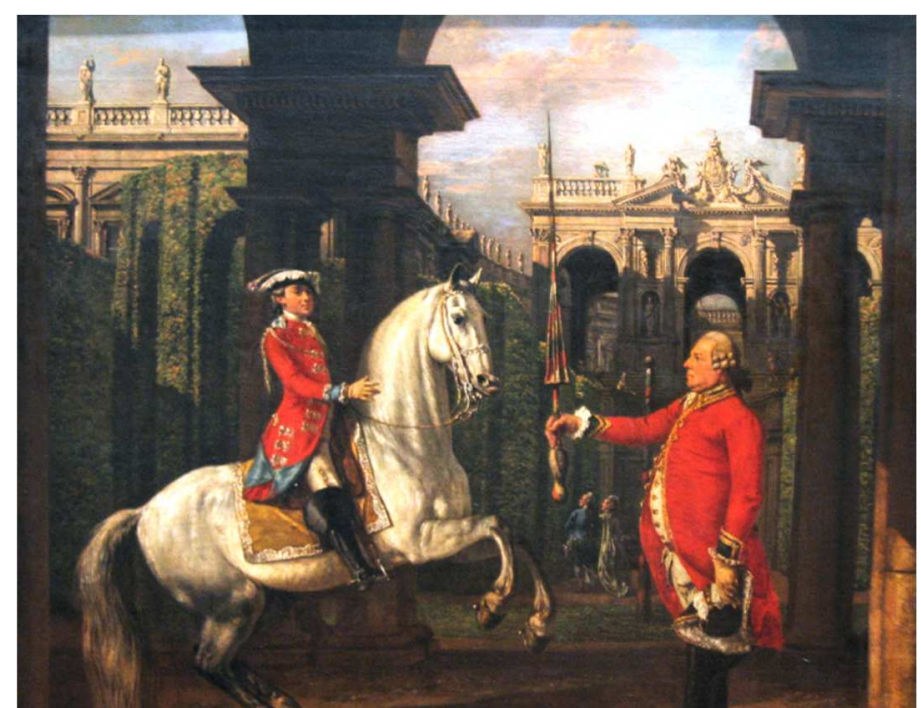

Figure 1. High School equestrianism in the Spanish Court Riding School of Vienna, 1773; painting by Giovanni Canaletto Source: https://de.wikipedia.org/wiki/Hofreitschule system and mathesis universalis was a common denominator of knowledge patterns in the fields of biology (Linné), language, and economy (mercantilism).

After this period of social discipline, the picture of social geometrical equestrianism changed once again. Beginning in England during the seventeenth and eighteenth centuries, horse racing spread in popularity (Kloeren, 1985). New patterns began to dominate that were marked by measurable achievement, competition, records, speed, and acceleration. Horse races expanded from around 1800 on the European continent and in the Scandinavian north, as well. Baroque figure riding disappeared more or less and only survived as a sort of 
museum-like display that still can be seen at the Spanish Court Riding School in Vienna. Dressage riding transformed the courtly art of equestrianism into a sport where results were quantified and measured using point systems. The use of the stopwatch for measuring the results of races was constructed in England in connection with horse racing and betting from 1731 onwards, and was also used to measure pedestrianism, the foot races of human athletes, after 1800. The stopwatch became an iconic symbol of modern sport culture and was also introduced into industrial production in the early twentieth century.

The change of configurations in equestrianism was connected with a shift in horse breeding. The Baroque art of the High School demanded a voluminous horse, which filled empty space. In paintings and copper engravings, this was often pictured in connection with courtly architecture, which underlined the static character of "postures" (Fig. 1).

Quite different was the breeding ideal of modern racing horses. In this case, speed was the main determinant. In popular racing pictures after 1800 , one can see a very different horse race in green nature or on turf. Furthermore, horses were pictured in a long, stretched form, nearly like an arrow. This did not at all correspond

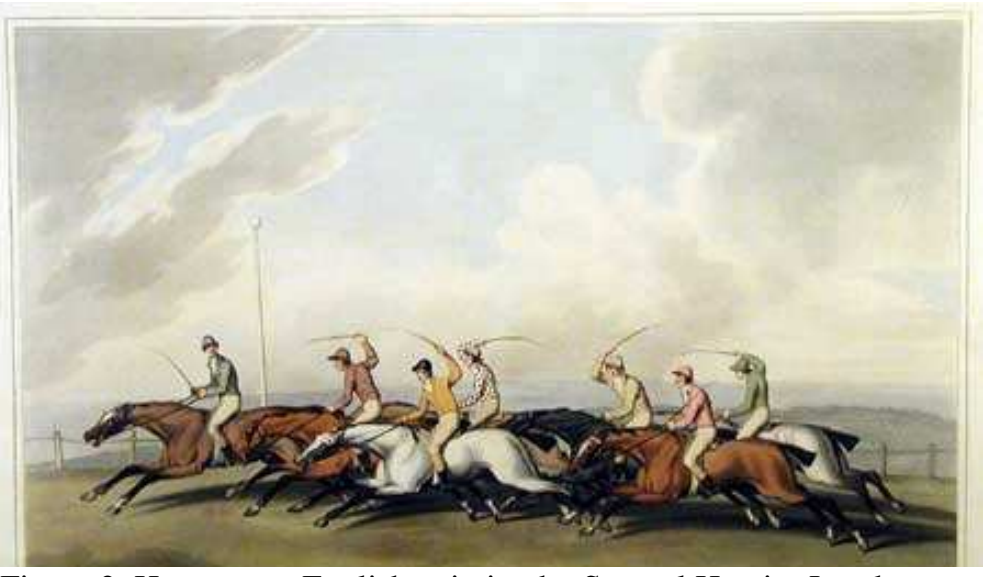

Figure 2. Horse race; English painting by Samuel Howitt, London 1807 (1756/57-1822)

Source: http://www.aradergalleries.com/detail.php?id=1418 to the form of a gallop in reality, but rather symbolically expressed the figure of the horse and rider as a streamlined projectile in acceleration. With a new form of society came a new type of time dynamics (Fig. 2).

Alongside horse racing, other established popular games, competitions, and exercises were subjected to the new pattern of temporal streamlining, too. Other sports disciplines, which until this point had been unknown, were also created on this basis: water sport (swimming races), winter sport (skating, tobogganing, and skiing) with time measurements, and technical speed sport, such as cycling and automobile sport.

\section{Sport research discovers the relativity of sport}

Sociologists discovered the historical and cultural significance of these changes during the 1970s and 1980s. Until this point, the dominating historiography of sport had "archaized" the process and drafted an evolutionist picture of sport as a universal activity existing from the Stone Age and the ancient Greek Olympics until the present time, with a continuous line from the "primitive" to the "modern".

Some of the first impulses for the new critical studies came from the sociologist Norbert Elias (Elias, \& Dunning, 1982, 1986). In several articles and unpublished fragments, he explored the revolutionary dimensions of English sport in detail (Haut, 2013). In this sociological perspective, the Olympic athletics of ancient Greece and the English sport of the eighteenth and nineteenth centuries were no longer the same.

Parallel to Elias' findings, studies of sport history showed concrete connections between the new achievement orientation and rationalization of sport on one hand and the behavioral patterns of industrial culture on the other. Sport was revealed as part of societal patterns characterized by achievement, suspense, and speed. Both in sport and in the world of production, the actors began to "measure, accelerate, and produce" (Eichberg, 1973, 1978).

Allen Guttmann (1978), who came from studies in American literature, broadened these insights and defined sport according to seven criteria:

- secularization,

- equality of starting conditions,

- specialization of roles, 
- rationalization,

- bureaucratic organization,

- quantification,

- competition for records.

This description became the international standard and established the specific modernity of sport within historical understanding. However, some questions also arose with this tabular list. How was the empirical recital of history related to eventual theoretical connections? If sport was described as a bodily-practical expression of the modern Weltanschauung (Guttmann, 1978, p. 85), this could be understood as an idealistic, i.e., idea-based interpretation, proceeding from a superstructure of thinking top-down to the basis of practical doing, instead of going bottom-up from practical movement. This picture could be seen as a return to evolutionist imaginations, establishing an overall theory of modernity and a dualistic distinction between premodern and modern life.

A methodological problem also arose with the abstraction of the categories. Could it be possible to find an intermediary level between pointillist historical-empirical evidence and sociological abstraction? There was a far distance between the concrete history of riding, ball games, and fencing on one hand and high-level abstractions such as rationalization, secularization, and bureaucratization on the other. Could there be a level of analysis somewhere in between?

Much more abstract was the description of social and cultural conditions in some other sociological approaches based on the system theory of Niklas Luhmann (Tangen, 1997). Here, sociologists continued the assumptions of evolutionism, now as a "theory of modernization". Sport was seen as a universal system of communication between human beings, unfolding step by step in an evolution from competitions in archaic "high cultures" from ancient Greece and Rome to the Middle Ages, and finally to modern sport. According to the system-theorists, society was differentiated into three steps:

- segmented differentiation, in archaic times, when the single part systems were not connected,

- stratified differentiation, which created order in hierarchical societies of castes or classes,

- functional differentiation, which characterized modern society.

In this imagination, modern sport represents the third, functionalist period, which, with undertones of evolutionism, is regarded as the peak of history (though sport sociologists who follow Pierre Bourdieu's analysis of class habitus have meanwhile neatly documented - but also nuanced - the continuity of the hierarchical patterns of taste and body-cultural practice in modern society). Sport, which had earlier been part of festivities and became integrated into educational and medical systems beginning in the eighteenth century, now obtained an autonomous status and followed its own "code". It was systemically "out-differentiated".

However, the system-theoretical concept of differentiation (Ausdifferenzierung) presupposed a universal, one-dimensional measure - the development only went in one direction. The theory of systems did not consider opposite processes that could eventually imply dedifferentiation, such as structural changes or even revolutions. Furthermore, the system-theoretical concept of "function" became the basis for a new essentialism that could confirm what was functional and correct, while other phenomena were eliminated as being "dysfunctional" and useless. A highly sophisticated doctoral dissertation from the system-theoretical school placed all of these theoretical keywords in its title: system, evolution, function, archaic, and modern (Tangen, 1997).

\section{Towards the configurations of modern sport}

In contrast to modernization theories, system theory, and functionalism, configurational analysis was developed as a more historical-empirical method (Eichberg, 1978). It tried to find an intermediary level between concrete historiographical empirical descriptions on one hand and high-level abstractions on the other. Evolutionist implications were avoided, as they threatened Norbert Elias' theory of the process of civilization (from primitive violence to civilized behavior), Guttmann's thesis of modernization (from ritual to record), 
and the theory of systems (from segmented and stratified cultures to functional differentiation).

The approach of configurational analysis started by comparing three historical movement cultures: old folk games from medieval and Early Modern times, noble exercises from Early Modernity, and modern sport in industrial culture. The comparative attention was directed towards the configurations of movement activities: their social time, social space, energies and atmospheres, interpersonal relations, and objectifications, as well as - as part of a sort of superstructure - their organization and ideas (see the Danish handbook with case studies of configurational analysis: Mindegaard et al., 2014).

\section{The genesis of modern sport}

The approach, thus, focused on historical change. From the eighteenth to the nineteenth century, a shift of body culture transformed older practices or brought new movement activities forward.

Equestrianism changed - as described above - from the geometrical riding of figures to timed races.

The foot race, jump, and cast were transformed from popular amusement - as part of festivities, carnival tournaments, and records of curiosity - to basic athletic exercises. They became part of competitions concerning centimeters, grams, and seconds, the new c-g-s sport.

Older water and winter activities were sportified as new competitions of speed and acceleration. Technical sport, such as cycle and motor sport, appeared as something completely new.

Among martial arts, noble fencing had once dominated for three centuries as a graceful geometrical art, side by side with the bloody duel. In England, people began to turn to boxing, which as a fight of achievement became the characteristic fighting art of modern industrial sport and - in line with the stopwatch - an icon and symbol for modern sport more generally.

Ball games in courtly society had once been dominated by ball-house tennis or court tennis, for which a specialized architecture of courts and ball-houses was erected all over Europe at universities, noble academies, and royal courts. Yet suddenly, this game became marginalized and was outpaced by football. Soccer and rugby focused on achievement, suspense, and speed - and they brought results that could be compared across time and space.

In the world of dance, choreographic court dances such as the minuet disappeared and were replaced by forward-directed whirl dances, beginning with the waltz. Later on, dance sport was developed as a competition measured by certain newly invented point systems.

Gymnastics was created as a completely new discipline in the same historical period, though continuing and transforming some older practice forms from vault jumping and military exercises. Educators invented new activities with or without the need of an apparatus and integrated them into new "systems" of (national) educational gymnastics, which were supposed to progressively raise the skill and national energy of the youth.

Were these changes just accidental inventions or punctual swings of fashion? Or were they significant in their mutual connection and, furthermore, through the more sweeping connection to social change and cultural shift? In order to answer questions like these, research began focusing on the shifting configurations of sport and movement.

\section{Shifting configurations of sport: The basis of practice}

The space of movement culture where play and dance took place was, thus far, the life world of the people. The preferred places were the village green, the street, the market place, or the church yard. Pieter Bruegel, the painter of Flemish farmers' life, documented this in his pictures.

From here, the epochal change went towards specialized sport and gymnastics facilities. During the seventeenth and eighteenth centuries, the nobility had already created specialized buildings for courtly exercises, fitting to their geometrical movement choreographies and separating them from the other social 
classes. Dancing halls were built for courtly dance and festivity, as were fencing rooms, riding halls for figure riding, and ball houses for court-tennis, jeu de paume.

After 1800, however, all these buildings were more or less deserted and transformed to have other functions, such as hospitals, libraries, and assembly halls. This shift became a revolutionary symbol when the representatives of the French estates met in 1789 in a ball house in Versailles and confirmed by oath - the famous serment du Jeu de paume - that they would not leave before France had a constitution. Though this activity took place in a hall of play, this was certainly no longer play. In place of the previous halls, new facilities were created for sport, especially straight-lined race tracks. This was the beginning of the artificial landscapes of modern sports, with their mono-functional parcels (Eichberg, 1986; Bale, 1996).

The time of movement culture during the period of noble exercises was marked by repetitive and circular movements. Sport shifted towards a focus on "progress", a sped-up forward movement. While measure, cadence, and the regularity of rhythm had played a central role in aristocratic exercises, sometimes supported by the mechanical device of the metronome, sport was mostly concerned with acceleration, which was supported - and generated - by the stopwatch.

Thus far, folk games had followed a time pattern which was linked to the cyclical rhythm of celebration and to the here-and-now of festivity. The funny carnival tournaments did not require systematical training. In contrast, sport and gymnastics developed training as a successive and progressive building of achievement and records.

Furthermore, slow movements and exercises of force, such as wrestling and tug-of-war, had so far dominated among the popular games and competitions. Sport, in contrast, gave priority to faster, pointed forms of fights or competitions. Sport built up a progressive suspense, especially in boxing, soccer, and foot races. The Danish sports commentator Gunnar "Nu" Hansen became prominent on the national scale thanks to his excited cries of "nu": "Now... now... oh no... now it happens!"

This pattern of speed and acceleration generated the particular form of suspense that became characteristic for modern sport.

The energy of movement culture, also called atmosphere or Stimmung (voicing), became marked by a certain suspense, a thrill of expectation, in modern sport. Sport developed an atmosphere of forward-directed tension and excitement, which made the old popular games and the noble exercises "boring". This happened at the same time that new genres of suspense, such as the criminal novel, appeared in modern literature after 1800 in the works of Edgar Allen Poe and others. Before that time, certain gothic histories and narratives about robbers and cruel, shocking events were already popular, but these were more frightening than suspenseful. As with boxing and football, it was only in modern times that the criminal novel unfolded as one of the typical and dominant modern literary genres. At the same time, physicists turned their attention towards the phenomena of energy and developed, in the time of Hans Christian Ørsted, the modern concepts of energy, including electric voltage (Nitschke, 1969).

The new focus of sport on progress was productive, but it did have its drawbacks: laughter, an important part of the folk carnival, disappeared from competitive sport. Whilst popular three-leg races and sack races staged the grotesque body of the human being, its limitations and stumbling movements, and gave place to laughter and fun, the new production of results demanded serious concentration from both the actor and the spectator. Stumbling became a mistake that was to be deplored and was no longer enjoyed as a fun part of festive togetherness; and whilst the fool in earlier shooting competitions and popular games had had a central position - as "referee", "festive speaker", or by handing over "shame prizes" - serious bureaucratic "officials" took over the roles of regulating and controlling the event and the award ceremonies. Neither the modern trainer nor the functionary of sport is a fool.

The interpersonal relations of movement culture were characterized in older popular culture by a sort of jousting or tourney where the winner stood against the loser. This losing, however, was not regarded as failing or evaluated by absolute criteria as in sport. Fights and competitions were rather a question of personal 
challenge and could have elements of teasing and hoaxing. Combat did not aim to produce measurable results to allow for ranking. This is, however, what sport developed, creating a new pyramid of achievement. In the new system, the winner was at the top, whereas the losers made up the broad base of the pyramid. Even in the "classless" Soviet Union, officials did not hesitate to present sport as a hierarchical order of "classes". The power of the new configuration was evidently stronger than the official "classless" ideology.

At the same time, the ritual forms of popular games were transformed into antagonistic relations where boxing and football became models. The folk games that aimed to produce a "loser" - the so-called scapegoat games - disappeared from the world of sport and only kept their place among children's games, such as in Danish kispus (Møller, 1990/91, vol. 2, pp. 23-24).

Another important change concerned gender. Gender was regarded and is sometimes still regarded as something "natural" and traditional. In modern sport, activities became gender separated in a way that had never been seen before. This separation demanded control, which was established by specialized gender tests that became more and more sophisticated starting in the 1960s (Cole, 2005). Their purpose was to make the principles of "men against men" and "women against women" objective. Gender testing proved, however, to be impossible and was officially abolished as a general practice of control in 1999/2000 for being "invasive, humiliating, and potentially psychologically damaging". However, the principle of gender separation in sport remained unchanged. The only exception among the Olympic disciplines is dressage riding (having roots in pre-modern noble exercises), where men and women compete against each other on equal terms.

Gender separation in competitive sport went hand in hand with another segmentation where "men compete in sports" while "women gracefully participate in dance and gymnastics". This was related to the distinction between "production" and "reproduction". The man produces, whereas the woman reproduces; this idea became one of the basic assumptions of the economy of industrial patriarchy, for which sport delivered the ritual (Eichberg, 2016, ch. 4).

Further relations that were important in this epochal shift were panoptical. As Foucault (1975) showed for the case of societal punishment, a change occurred from bodily chastisement to the hierarchical and panoptical power of the modern prison (Foucault, 1975). Power organizes the survey from "those up there" down to the integrated "individual". In contrast, the paintings of Bruegel presented the popular games as a world without survey. The panoptical relations of movement culture became visible in the gymnastics exercises in the rank and file, which had some roots in military exercises from the seventeenth century, and later in the staging of sport for an audience in a stadium.

Another type of relational system building has unfolded in what has been called the totalization of sport (Heinilä, 1982). In elite sport, it has become less and less the single athlete who produces the results and more a complex system and network of trainers, medical doctors, experts of nutrition and doping, managers, PR assistants, researchers in sport physiology, and managers. The single athlete is still honored, but his or her achievement is produced by a whole system. This system is a modern configuration of relations that has not been used in the past.

Through the objectification of movement culture, the genesis of modern achievement comes to expression in a particular clearness. In folk games, the name of the winner was remembered, but not the results in numbers. We do not know measured results from the Olympic Games of ancient Greece, though devices for measuring - including hourglasses - at that time were in use. Neither the competitors nor the spectators were interested in quantified results. The same is true for medieval tournaments and for competitions in the old Scottish Highland Games. It was through modern English sport and its culture of betting that quantification using centimeters, grams, and seconds (c-g-s) became a driving force, connecting sport with the stopwatch and creating a push to achieve new records. Where a linear measurement in c-g-s was impossible - as in sports dance, ice skating, and gymnastics - systems of points were invented in order to correspond to the new demands of objectification.

This method of making flowing movements "objective" can be compared with the position of the product and commodity in industrial society. It implied a reification of human relations and was also connected 
with the building of pyramids between the very top and the broad bottom. Achievement, measurement, and ranking transformed the older games and contests into modern processes of production. Through this transformation, play and games shifted from festivity to a professional discipline similar to industrial work.

\section{The superstructure}

The organization of movement culture had a local character for several centuries, being connected with festivity and celebration and placed somewhere between tradition and spontaneity. Modern sport, in contrast, was organized into clubs and associations, national federations, and international umbrella organizations. The institutionalized superstructure of sport resembled, thus, the pyramid structure, which was promoted through the principle of achievement, as well as the industrial enterprise and the bureaucratic state.

At the same time, a certain contradiction developed inside the pyramid. On one hand, some organizations represented broad mass sport, gymnastics, and "sport for all". On the other hand, some sport organizations focused mainly on elite sport. In Denmark, this contrast is expressed through the two competing national federations, the Danish Gymnastics and Sport Associations (DGI) and the Olympic Sport Federation of Denmark (DIF). In contrast, other countries have established a single unitary national organization, although similar tensions have developed inside this body. For instance, Norwegian sport (with the central federation NIF) is marked by tension between the regional NIF districts (broad sport) and the NIF top (elite sport). These tensions are more than ideological - they are structural. They have often been linked to an alternative for sport organizations, based either on regional units (broad sport) or on sport disciplines (elite sport).

The ideology of movement culture makes up a further superstructure above body cultural practice. It is the level of ideas, values, and ideologies, and is not so far from religion. Whereas traditional folk games were integrated into the - often religious - connection of rituals and celebrations, sport became a sort of substitution for religion. In some countries, church and sport long fought over the sacredness of Sunday, and often the church lost (Watson, \& Parker, 2012, pp. 125-126). Nowadays, this conflict reappears in some forms of Wahhabi Muslim fundamentalism, which tries to suppress traditional games and festivities, sport, music, and movies.

The ideological superstructure shifted as part of a broader cultural change. Whereas religion in Western countries was for centuries a local common practice - with ritual, dance, song, taboo, holy objects, holy places, incense, healing, and magic - modern Europe transformed religion into a question of faith, understood as a theoretical system under control of the theological clergy. This was especially true for Protestantism, while Catholicism retained more of the magical elements of folk rituals (Hauschild, 2002). Thus in Protestantism, an empty space opened between religious belief and ritual bodily practice, and this space was filled by sport (Centring, 1986; Eichberg, 1991). This was the background for the historical imbalance that caused sport and gymnastics to first develop in Protestant countries before spreading to Catholic and Eastern Orthodox regions. The ingenious idea of Pierre de Coubertin was to reestablish the Olympic Games around English sport as a practical cult of achievement and as part of an "Olympic religion", which had new-pagan undertones. Later on, the new fitness culture developed on a similar line as a sort of "postmodern" fitness religion, now centered around the self-care of the "single individual" (Kirkegaard, 2007).

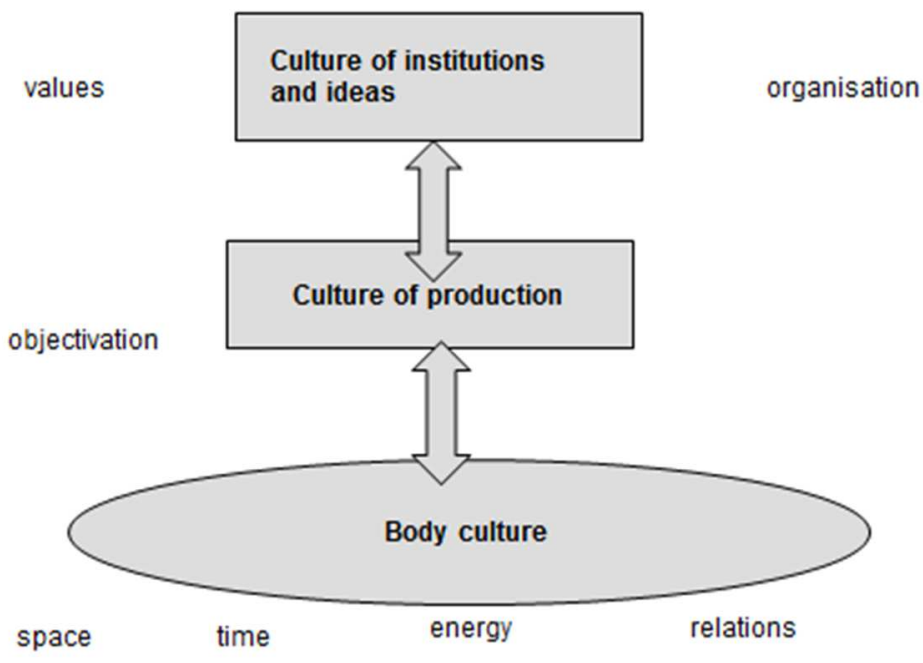

Figure 3. Configurational analysis

Source: own study. 
The pattern of configurations (Fig. 3) should, however, not be misunderstood as a system of neatly delimited little boxes. Rather, it should be used for analytical understanding.

\section{Shift of movement culture and social change}

The configurations of movement culture can also aid in understanding the patterns of social life more generally. The revolution of the movement configurations that took place between 1770 and the 1820 s was related to the Industrial Revolution as a fundamental cultural change (Nitschke, 1975). The gymnastic and sportive body presents information about the basic conditions of social life, such as:

- the functional parceling of space, for instance in urban planning,

- the fascination with "progress", speed, acceleration, and life as a forward-directed career (Eichberg, 2016, ch. 10),

- the modern taste for suspense,

- competitive patterns of capitalist production,

- the reification of industrial "productivity" (Eichberg, 2016, ch. 4).

However, the findings of configurational analysis have not remained undisputed. Conservative historians of sport have defended the idea of eternal sport with evidence for some pre-modern quantifications of sport results (Carter, \& Krüger, 1990). For instance, one referred to Japanese Chikaraishi, a form of stone lifting, which since at least the eleventh century has been connected with the religion of Shinto, its shrines, celebrations, and divination techniques (Krüger, \& Ito, 1977). However, though Chikaraishi has also been practiced as a sort of exercise of force in modern times, it has never become a real modern sport.

These and similar cases show that an analysis is required to bring together punctual historical "facts" with deeper cultural patterns. Configurations are culturally significant due to the connections they establish between concrete human practice and more comprehensive social patterns.

In order to understand current affairs through the analysis of configurations, the question of whether we are still "modern" can be addressed. Foucault (1966) touched on this question when he explored the configurations of knowledge. The current tendencies of play and movement culture can tell us something about the crisis of modernity - about "post-industrial" or "postmodern" conditions - and about continuity or discontinuity. But what do they say? What does it mean if parts of modern sport enter into a new culture of event, entertainment, and festivity?

\section{The trialectics of modern sport}

In connection with such questions, configurational analysis has encouraged reflection about the inner contradictions of sport. Sport is not just one uniform phenomenon. Differential phenomenology has discovered what is called the trialectics of movement culture. In modern society, tension has developed between sport of achievement, the fitness model, and alternative forms of popular play and movement (Eichberg, 2004).

Mainstream sport is characterized by the dominance of the objectification and reification of movement - results and records measured in c-g-s and points. This orientation towards production is connected with the time of training (continuity, intensification, systematical preparation) and the specialized spaces of sport (highly parceled facilities for different sport disciplines). The energy and atmosphere of sport is marked by expectation, thrill, and suspense, which is directed towards the outcome. The relations within sport are dominated by competition between teams or single athletes, building hierarchical relations among the competitors, and the development of more and more refined, authoritarian expert systems - the totalization of sport.

Parallel to this configuration, through more than two centuries of modern sport history, patterns of physical exercise, gymnastics, and fitness have developed. Here, objectification in the form of quantification and record play a much lesser role while the production of pictures - smiling people in rank and file and mass ornaments - are more highly valued. Time and training are invested more into joint rhythm than into individual intensification, and in contrast to the one-sided youth focus of sport, there is more place for elderly people. The space of gymnastics is less differentiated after specialized disciplines, though new parceling may develop 
with the spread of fitness centers. The atmosphere is more marked by community and its festive voicing, which is celebrated by minor and larger gatherings (Eichberg, 2010, ch. 7). Relations are less dictated by competition and more by community and group cohesion, which is displayed for an audience and contributes to the common atmosphere. The relationship between the gymnast and the gymnastics leader or instructor may have an authoritarian character, which in fitness culture can be reproduced through the "personal trainer". In the superstructure, "health" plays a more important role, which in gymnastics, however, is linked to the value of identity-related we-integration in local associations. Over the course of history, this we-identity has sometimes taken on the character of national patriotic exclusivity, but it could also facilitate social educational inclusion. With fitness culture, this collectivity is weakened in favor of more individualized patterns, but group building seems to reproduce itself inside fitness centers, too (Kirkegaard, 2007).

Both gymnastics and sport also integrated some elements from popular movement culture and play, making up a pattern. Among these elements were certain old games that sometimes became re-actualized in modern alternative connections, as in the New Games of Californian type and in Danish Football for Fun. In this third field, encounters between human beings dominate, as do the atmosphere of festivity and the joint culture of laughter. Neither the sportive quantification of achievement nor the pyramids of competition are decisive here, and the space of movement is not functionally parceled. The competitor is not met as the superior or inferior in achievement, but as the other in an encounter of difference.

Under the aspect of identity, the typology looks like this:

- Achievement, competition, result: "We won" versus "We lost", Identity of production - (Olympic) sport and ranking,

- Discipline and fitness: "Look who we are!", Identity of integration - Gymnastics in rank and file,

- Festivity and play: "Nice to meet you. Who are you?", Popular identity - Carnival and folk games as a dialogical encounter.

These three different patterns of sport do not form strictly delimitated "little boxes". Instead, their practical contradictions express dialectical (trialectical) tensions with societal significance (Eichberg, 2004).

\section{From conceptual essentialism to method}

If we pay attention to the configurations of movement culture, the established discussion about the "origin of sport" is relocated from the traditional questions of "When?" and "Where?" to the methodological. The question of whether sport is ancient and universal or typically modern cannot be answered by conceptual realism in the understanding of Plato: that there exists something like "sport" in the heaven of ideas which human beings have fetched down to earth and practice. In the spirit of conceptual essentialism, one identifies the concept of sport with all sorts of activities: the javelin throw on Stone Age rock carvings, the ritual shooting of Egypt's pharaohs, ancient Greek funeral rituals and Olympic festivities, the challenges of the old Nordic Vikings, medieval tournaments, Baroque noble exercises, folk games, and children's play. Configurational analysis, in contrast, heightens the particular patterns of these games, rituals, and competitions, as well as the difference between these activities and the modern sport of achievement.

The essentialist belief in the universality of sport is thus questioned as such: How can we say something about the social connection of human movement practices?

\section{... and back to the culture of riding}

At this point, we can return to the culture of riding, which, like the icon of the stopwatch, became paradigmatic for modern sport culture. During the past few decades, some remarkable innovations have occurred (Wagenmann, \& Schönhammer, 1994; Eichberg, 2008). Statistics about people's participation in sport show certain characteristic gender differences in equestrian activities. In Denmark in 1998, women dominated in the activity of riding by $71 \%$. In Germany, riding was ranked third for organized sport for girls, 
while this activity ranked far lower among boys. Young boys play football, while girls prefer riding - this marks two extreme points in gender imbalance.

This difference may have a deeper meaning for cultural practices. In countryside stables, young girls care for horses, ride them, and create relationships with them. A whole media market has unfolded around this activity with horse magazines, comic strips such as Wendy, and kitschy horse novels targeting girls of a certain age, just after Barbie dolls and princess magazines. So far, girls' culture around riding has only exceptionally attracted attention in the field of sport and in sport research.

When seen from a historical perspective, the gender imbalance in riding is a surprising paradox. For centuries, males most commonly mounted horseback. In agriculture, the horse was a part of the male working sphere outside the house, while the female cared for the household. Whether in the culture of medieval knights, tournaments, and hunting, or the cavalry of the Early Modern state and the exercises of noble academies, riding was almost exclusively for males. Statues and monuments of kings showed the he-man on horseback. This imbalance continued or was renewed with equestrian sport in eighteenth century England through fox hunting and competitive turf racing. (An exception was dressage riding, as mentioned above.) Nowadays, trotting sport and gallop sport on TV are favorites primarily for men - especially for men with lower education levels rather than for women.

Seen in this light, the current gender profile of riding represents a remarkable rupture. With configurational analysis at hand, it can be asked whether girls' riding culture is just a ruffle in the surface of history or whether the change has a deeper meaning connected with social relations.

\section{REFERENCES}

Bale, J. (1996). Landscapes of Modern Sports. London: Leicester University Press.

Carter, J. M., \& Krüger, A. (Eds.) (1990). Ritual and Record. Sports Records and Quantification in Pre-Modern Societies. New York: Greenwood.

Centring (1986). Special issue Sport og religion/Sport and religion/. Gerlev/Denmark, 7, 1.

Cole, C. (2005). American fantasies: Enchanted sporting bodies \& sex testing. Imeros, Journal for Culture and Technology, 5(1), 257-266.

Dunning, E. (1973). The structural-functional properties of folk-games and modern sports. Sportwissenschaft, 3, $215-232$.

Eichberg, H. (1973). Der Weg des Sports in die industrielle Zivilisation/The way of sport towards industrial civilization/. Baden-Baden: Nomos.

Eichberg, H. (1978). Leistung, Spannung, Geschwindigkeit. Sport und Tanz im gesellschaftlichen Wandel des $18 . / 19$. Jahrhunderts /Achievement, suspense, speed. Sport and dance in the societal change of the $18^{\text {th }}$ and $19^{\text {th }}$ centuries/. Stuttgart: Klett.

Eichberg, H. (1986). The enclosure of the body. On the historical relativity of "health", "nature" and the environment of sport. Journal of Contemporary History, 21, 99-121.

Eichberg, H. (1989). Festung, Zentralmacht und Sozialgeometrie. Kriegsingenieurwesen des 17. Jahrhunderts in den Herzogtümern Bremen und Verden /Fortification, central power, and social geometry. The seventeenth century's war engineering in the duchesses of Bremen and Verden/. Cologne, Vienna: Böhlau.

Eichberg, H. (1991). Das Sinnliche der Kasteiung. Über Sport, Körper und Katholizismus /The sensuality of asceticism. About, sport, body, and Catholicism/. In M. Kintzinger et al. (Eds.), Das Andere Wahrnehmen. Beiträge zur europäischen Geschichte /To perceive the other. Contributions to European history/ (pp. 715-731). Köln: Böhlau.

Eichberg, H. (2004). The People of Democracy. Understanding Self-Determination on the Basis of Body and Movement. Århus: Klim.

Eichberg, H. (2006). Køn i bevægelse /Gender in movement/. In A.L. Poulsen \& E. Trangbæk (Eds.), Kvinder, køn og krop - kulturelle fortallinger /Women, gender, and body - cultural narratives/. Odense: Syddansk Universitetsforlag. 111-116. - Enlarged (2008). Idrottsforum. 103, 12.12.2008.

Eichberg, H (2010). Bodily Democracy. London: Routledge. 
Eichberg, H. (2016). Questioning Play. London: Routledge.

Elias, N., \& Dunning, E. (1982). Sport im Zivilisationsprozess /Sport in the process of civilization/. Münster: Lit. - 1986 under the title: Quest for Excitement. Sport and Leisure in the Civilising Process. Oxford: Basil Blackwell.

Foucault, M. (1966). Les mots et les choses. Paris: Gallimard. - English (1970). The Order of Things. An Archeology of the Human Sciences. New York: Pantheon.

Foucault, M. (1975). Surveiller et punir. La naissance de la prison. Paris: Gallimard. - English (1975). Discipline and Punish. Harmondsworth: Penguin.

Guttmann, A. (1978). From Ritual to Record. The Nature of Modern Sports. New York: Columbia University Press.

Hauschild, T. (2002). Magic and Power in Southern Italy. London: Berghahn.

Haut, J. (2013). Norbert Elias` unvollendete Sozialgeschichte des Sports. Überlegungen anhand unveröffentlichter Archivmaterialien /Norbert Elias' uncompleted social history of sport. Reflections based on unpublished archive materials/. SportZeiten, 13(1), 45-67.

Heinilä, K. (1982). The totalization process in international sport. Sportwissenschaft, 12, 235-254.

Kirkegaard, K.L. (2007). Fra muskelmasse til massebevagelse. Indblik i den kommercielle fitness-sektors historie /From muscle mass to mass movement. History of the commercial fitness sector/. Copenhagen: Idrættens Analyseinstitut.

Kloeren, M. (1985). Sport und Rekord. Kultursoziologische Untersuchungen zum England des sechzehnten bis achtzehnten Jahrhunderts /Sport and record: Cultural sociological studies on sixteenth to eighteenth century England/. Münster, Germany: Lit.

Krüger, A., \& Ito, A. (1977). On the limitations of Eichberg's and Mandell's theory of sports and their quantification in views of Chikaraishi. Stadion, 3, 244-52. Answers from H. Eichberg and R. Mandell: 253-257.

Mindegaard, P., Andkjær, S., \& Svendsen, A.M. (Eds.) (2014). Bevagelser og kropskulturelle mønstre. Konfigurationsanalysen i teori og praksis. /Movements and body cultural patterns. Configurational analysis in theory and practice/. Odense: Syddansk Universitetsforlag.

Møller, J. (1990/91). Gamle idratslege i Danmark/Old movement games in Denmark/. New ed. Vols. 1-4. Gerlev: Idrætshistorisk Værksted 1997.

Nitschke, A. (1969). Energieübertragung, Ströme, Felder und Wellen. Beobachtungen zur Lyrik von Goethe, Novalis und Eichendorff /Transformation of energy, power flows, fields, and waves. Observations of poems of Goethe, Novalis, and Eichendorff/. In H. Kreuzer (Ed.), Gestaltungsgeschichte und Gesellschaftsgeschichte /History of form and history of society/ (pp. 201-223). Stuttgart: Metzler.

Nitschke, A. (Ed.) (1975). Verhaltenswandel in der Industriellen Revolution. Beiträge zur Sozialgeschichte /Change of behaviour in the Industrial Revolution. Contributions to social history/. Stuttgart: Kohlhammer.

Oestreich, G. (1969). Strukturprobleme des europäischen Absolutismus /Structural problems of European absolutism/. In Oestreich. Geist und Gestalt des frühmodernen Staates. Ausgewählte Aufsätze /Spirit and form of the Early Modern state. Selected essays/ (pp. 179-197). Berlin: Duncker \& Humblot.

Tangen, J.O. (1997). Samfunnets idrett. En sosiologisk analyse av idrett som sosialt system, dets evolusjon og funksjon fra arkaisk til moderne tid /Sport of society. A sociological analysis of sport as social system, its evolution and function from archaic to modern times/. Bø: Høgskolen i Telemark.

Wagenmann, S., \& Schönhammer, R. (1994). Mädchen und Pferde. Psychologie einer Jugendliebe /Girls and horses. Psychology of a youth love/. Berlin \& München: Quintessenz.

Watson, N.J., \& Parker, A. (Eds.) (2012). Sports and Christianity. Historical and Contemporary Perspectives. London: Routledge.

\section{AUTHOR'S ADDRESS: Henning Eichberg}

University of Southern Denmark

Campusvej 55, 5230 Odense M

Denmark

E-mail: heichberg@health.sdu.dk

Received: 3 October 2016; Accepted: 24 November 2016 